Migration Studies - Review of Polish Diaspora nr 1 (171)/2019, http://www.ejournals.eu/Studia-Migracyjne/ DOI: $10.4467 / 25444972$ SMPP.19.007.10257

\title{
Doświadczanie nierówności w statusie społecznym i bullyingu w środowisku szkolnym. Percepcja dzieci polskich imigrantów w Norwegii
}

\author{
STELLA STRZEMECKA ${ }^{1}$ \\ KRYSTYNA SLANY \\ Uniwersytet Jagielloński
}

\begin{abstract}
W artykule analizujemy mozaikę niekorzystnych aspektów związanych z sytuacją społeczno-ekonomiczną dzieci polskich imigrantów w norweskim środowisku szkolnym. Główna uwaga zostaje zwrócona na doświadczane przez dzieci dyskryminacje, wynikające ze zróżnicowania statusu społecznego (w porównaniu z dziećmi norweskimi), wspomnienia i przeżycia przemocy rówieśniczej w postaci dręczenia (ang. bullying) oraz tworzenie indywidualnych strategii zaradczych w obliczu „pracy rówieśniczej". Dowodzimy, że manifestowane przez dzieci nierówności społeczno-ekonomiczne przejawiają się w aktach bullyingu. Ponadto ukazujemy rolę norweskiej szkoły i środowiska szkolnego w przebiegu integracji dzieci polskich imigrantów, kształtowania ich samooceny, oceny statusu społecznego rodziny oraz oceny poziomu zamożności kraju pochodzenia i przybycia. Artykuł bazuje na wynikach dwóch projektów badawczych: "Doświadczenia dzieci dorastających transnarodowo" (zadanie nr 5 prowadzone w ramach polsko-norweskiego projektu Transfam w latach 2013-2016) oraz "Proces adaptacji dzieci polskich imigrantów. Badania terenowe w Norwegii" (projekt doktorancki realizowany w latach 2013-2014 w Instytut Socjologii Uniwersytetu Jagiellońskiego).
\end{abstract}

Słowa kluczowe: migracja, dzieci imigrantów, szkoła, nierówności społeczno-ekonomiczne, bullying, perspektywa dzieci, praca rówieśnicza, Polacy w Norwegii

\section{Experiencing Inequalities in Social Status and Bullying within a School Environment. Perception of Children of Polish Immigrants in Norway}

This article discusses a mosaic of unfavorable aspects related to the socio-economic situation of children of Polish immigrants in the Norwegian school environment. The main focus is placed on

\footnotetext{
1 Adres do korespondencji: contact@stellastrzemecka.pl
} 
discrimination experienced by these children due to non-majority social status (as compared to Norwegian children). Moreover, we examine memories and experiences of peer violence in a form of bullying and individual coping strategies seen as 'peer work'. We demonstrate that socio-economic inequalities manifested by children can be seen in the bullying acts. In addition, we show the role of the Norwegian school and the school environment in a process of integration among the children of Polish immigrants. We note how it shapes their self-esteem, as well as assess social status of a family and the economic situation in the countries of origin and arrival. The article is based on the results of two research projects: Children's experience of growing up transnationally (Work Package 5 conducted within the Transfam project between 2013 and 2016) and The adaptation process of children of Polish immigrants. Field research in Norway (a doctoral project implemented in 2013-2014 at the Institute of Sociology of the Jagiellonian University).

Keywords: migration, immigrant children, school, socio-economic inequalities, bullying, children's perspective, peer work, Poles in Norway

\section{Wprowadzenie}

Zjawisko transgranicznych wędrówek ludności generuje wiele nierówności i problemów związanych z integracją społeczno-ekonomiczną nie tylko wśród samych migrantów, ale i szerszych struktur rodzinnych, instytucji oraz rynku pracy kraju napływu i kraju pochodzenia. Migracja sama z siebie ich nie rozwiązuje, lecz uruchamia w sposób niemalże lawinowy nowe problemy i wyzwania o różnorakim charakterze (Castles, Miller 2011). Jak pisze Thomas Faist (2016), nierówności kształtują migracje i nierówności są rezultatem migracji. Migracje ekonomiczne stanowią ważną strategię życiową jednostek, rodzin i grup, wpływają na trajektorie biegu życia nie tylko osób podejmujących decyzje migracyjne, ale i wszystkich członków rodziny, w tym dzieci. U progu XXI w. migracje zarobkowe dotyczą setek tysięcy polskich rodzin podejmujących coraz częściej decyzje osiedleńcze zarówno w tzw. starych, jak i w nowych krajach napływu (Wielka Brytania, Irlandia, Norwegia, Islandia itd.). W naszych badaniach nad migracjami międzynarodowymi Polaków (prowadzonych m.in. w ramach projektu Transfam ${ }^{2}$ ) interesuje nas sytuacja dzieci dorastających w polskich rodzinach transnarodowych w jednym z nowych krajów imigracji, a mianowicie w Norwegii ${ }^{3}$.

2 Transfam: „Rodzina ponad granicami. Decyzje demograficzne, strategie rynkowo-instytucjonalne, integracja ze środowiskiem szkolnym oraz życie codzienne polsko-norweskich rodzin transnacjonalnych" [tytuł oryg.: Doing family in a transnational context. Demographic choices, welfare adaptations, school integration and every-day life of Polish families living in Polish-Norwegian transnationality]. Projekt był finansowany ze środków Funduszy Norweskich w ramach Polsko-Norweskiej Współpracy Badawczej realizowanej przez Narodowe Centrum Badań i Rozwoju w ramach Norweskiego Mechanizmu Finansowego 2009-2014 na mocy kontraktu projektowego Nr. Pol-Nor/197905/4/2013.

${ }^{3}$ W kontekście współczesnej masowej emigracji zarobkowej Polaków (GUS 2016), Norwegia stała się ważną destynacją szczególnie po akcesji Polski do Unii Europejskiej w 2004 r. i po otwarciu europejskich rynków pracy oraz w kontekście światowego kryzysu finansowego z przełomu 2007/2008 r. (Friberg et al. 2014). Według danych szacunkowych Norweskiego Urzędu Statystycznego (SSB 2018) spośród wszystkich grup etnicznych, mieszkających w ponad 5 milionowym Królestwie Norwegii, Polacy tworzą największą grupę mniejszościową żyjącą na terenie tego kraju już od kilku lat. Liczba polskich obywateli w Norwegii 


\section{SM̂PP}

Artykuł pokazuje zjawisko nierówności w statusie społecznym i bullying w norweskim środowisku szkolnym z perspektywy dzieci polskich imigrantów. Podejmujemy temat nierówności i dyskryminacji w ujęciu, na które w szczególny sposób zobowiązani jesteśmy zwracać uwagę jako badacze/badaczki zjawisk socjopsychologicznych, a także jako uczeni/uczone zobowiązani/e do pracy nad poszukaniem rozwiązań problemów społecznych, które to rozwiązania znacząco mogą wpłynąć na jakość życia poszczególnych grup i jednostek. Eksplorując zjawisko nierówności i bullyingu w środowisku szkolnym wśród dzieci, pochylamy się nad problemem często "niewidocznym" dla dorosłych, bo ukrytym w głębi szatni albo w czeluściach internetu. Poruszamy także problem grupy, która pozornie mogłaby zostać uznana za płynnie przechodzącą proces adaptacji ze względu na fakt, iż dzieci polskie i norweskie nie są „silnie zróżnicowane etnicznie". Przyjmujemy, że system szkolny i środowisko szkolne kraju napływu odgrywa kluczową rolę w osiąganiu sukcesu integracyjnego, samooceny, oceny statusu społeczno-ekonomicznego swojej rodziny oraz postrzegania poziomu zamożności kraju pochodzenia i napływu. Obok formalnych programów włączających dzieci imigranckie w życie społeczno-kulturowe, pojawiają się zjawiska i procesy będące pochodną szerszych relacji społecznych, stosunków etnicznych, postrzegania obcokrajowców, ich pozycji w społeczeństwie przyjmującym, które niejednokrotnie odsłaniają wyzwania integracyjne, w tym indywidualne zmagania z trudnościami adaptacyjnymi. Podobnie jak rodzice migranci ekonomiczni, także ich dzieci na wstępie swej drogi adaptacyjnej znajdują się na pozycji odmiennej od tej, którą zajmują ich norwescy rówieśnicy i ich rodziny.

Migracja międzynarodowa i wejście w nowe środowisko szkolne jest „burzliwym przejściem" (ang. turbulent transition) w biografiach najmłodszych aktorów migracji (Callender 2012: 226). Dzieci muszą zmierzyć się w nowym kraju z różnymi wyzwaniami - m.in. zagrożeniem marginalizacją i dyskryminacją (Kalkman, Hopperstad, Valenta 2017; Kempny 2011), szokiem kulturowym (Strzemecka 2015; zob. Oberg 1960), zachwianym poczuciem bezpieczeństwa ekonomicznego rodziny (szczególnie w początkowej fazie post-migracyjnej; Hakkarainen 2018) czy dylematami związanymi z poczuciem tożsamości i przywiązania (Darvin, Norton 2014; Pustułka, Ślusarczyk, Strzemecka 2016), czyli rozterkami, które mają bezdyskusyjny wpływ na rozwój społeczny i emocjonalny oraz ich samopoczucie. Z badań wiemy (Sam, Berry 2006; Navas, Rojas, García, Pumares 2007; Zagefka, Tip, González, Brown, Cinnirella 2012), że zjawiska towarzyszące adaptacji - zwłaszcza w kontekście adolescentów-imigrantów - mogą stanowić istotną przeszkodę w procesie kształtowania

znacząco wzrosła w przeciągu 11 lat od 7580 w 2004 r. do blisko 100 tys. obywateli zarejestrowanych w 2016 r. (Iglicka, Gmaj, Wierzejski 2018). Badania pokazały (Huang et al. 2015), że większość (52\% respondentów) ma zamiar osiedlić się w Norwegii. Polacy cenią norweski standard życia, dający poczucie bezpieczeństwa ekonomicznego (m.in. stała praca, wyższe zarobki) i socjalnego („,państwo opiekuńcze”). Norwegia nie jest więc już krajem, w którym Polacy podejmują głównie pracę sezonową, ale także ściągają do niej swoje rodziny i wychowują dzieci (zob. Slany, Strzemecka 2016b). 
samooceny i identyfikacji. Zaznaczyć należy jednak, że nie wszystkie jednostki przechodzące proces przystosowania społecznego i kryzys adolescencji muszą stać się ofiarą bullyingu. Jednakże doświadczenie migracyjne może się sprzęgać z przemocą i wzmacniać poczucie dyskryminowania, co ma wpływ na dalsze funkcjonowanie dzieci imigranckich.

W oparciu o literaturę przedmiotu można stwierdzić, że temat odkrywania nierówności w odniesieniu do położenia społeczno-ekonomicznego, jak i bullyingu w środowisku szkolnym (badanego z perspektywy dzieci imigrantów) był do pierwszej dekady XXI stulecia w wielu krajach - zarówno tych o długim, jak i krótkim stażu imigracyjnym (Pasamonik 2013) - "jak słoń w pokoju" (Seeberg 2011: 6-9). Wraz z rosnącą "superróżnorodnością" (Vertovec 2007), rozwojem i rozprzestrzenianiem się paradygmatu społecznych studiów dziecka i okresu dzieciństwa (James, Jenks, Prout 1998) oraz zmieniającą się gwałtownie sytuacją społeczno-polityczną w Europie, począwszy od drugiej dekady XXI w. aż do dziś (Lafleur, Stanek 2016) temat ten zyskuje na popularności (Sauer, Ajanović 2012; Sime et al. 2017; Sokolowska 2016; Žakelj, Kralj 2012). W świetle współczesnej fali emigracji z Polski do Norwegii (Godzimirski et al. 2015; Friberg et al. 2014) oraz rosnącego zainteresowania badaniami z udziałem dzieci polskich imigrantów w Norwegii (Slany, Strzemecka 2015; 2016a, 2016b, 2017, 2018; Strzemecka 2015), analizujemy doświadczenia dzieci par polsko-polskich związane z postrzeganiem i odczuwaniem różnic w położeniu ekonomicznym względem dzieci norweskich oraz dyskryminacją, która przejawia się w aktach dręczenia w środowisku rówieśniczym. Rozważamy rolę środowiska szkolnego w kreowaniu i utrwalaniu nierówności pomiędzy dziećmi. Podnosimy również kwestię związku odmienności statusu społeczno-ekonomicznego i bullyingu z poczuciem identyfikacji i przynależności dzieci polskich imigrantów. Nasze badania sygnalizują pewne zjawiska i procesy związane z charakterem, przyczynami i konsekwencjami odczuwania zróżnicowań w statusie społecznym oraz bullyingu w norweskim środowisku szkolnym z perspektywy dzieci. Podkreślmy, że nie mogą być one generalizowane na wszystkich uczniów szkoły norweskiej, jak i na występowanie podobnych doświadczeń wśród dzieci z innych grup imigranckich. Stanowią jedynie pewną egzemplifikację negatywnych doświadczeń polskich dzieci w norweskiej szkole.

Artykuł składa się z czterech sekcji. W pierwszej pokazujemy szkołę jako jeden z fundamentalnych instytucjonalno-społecznych filarów integracji w analizowanym społeczeństwie przyjmującym. W części drugiej opisujemy nasze podejście metodologiczne, metody i techniki oraz pracę w terenie badawczym. W sekcji trzeciej prezentujemy kluczowe wnioski, które wyłoniły się z przeprowadzonych badań, pokazując zarówno podmiotowość i sprawczość dzieci imigrantów, jak i struktury ograniczające możliwość ich ekspresji oraz działań. W ostatniej części artykułu zawarłyśmy podsumowanie najważniejszych ustaleń, wskazując na główne implikacje praktyczne wynikające z naszych analiz. 


\section{SM̂PP}

\section{Norweska szkoła jako instytucjonalno-społeczny filar integracji}

Począwszy od pierwszej dekady XXI w., zagadnienie integracji dzieci imigrantów znajduje się na szczycie agendy politycznej UE ${ }^{4}$. Mimo iż Norwegia nie jest formalnym członkiem wspólnoty europejskiej, integracja społeczna dzieci imigrantów (w tym relacje interkulturowe w szkole) jest definiowana jako ważny obszar polityki równościowej, społecznej i imigracyjnej państwa norweskiego (Nikielska-Sekuła 2016). Norweska szkoła jest instytucją, której celem jest budowanie przyjaznej przestrzeni dla tworzenia relacji interetnicznych oraz osłabianie hierarchii w stosunkach większość-mniejszość. To właśnie w otoczeniu szkolnym kształtują się przyszłe relacje interetniczne i uznanie różnorodności. W norweskim społeczeństwie wielokulturowym szkoła jest ważną formalną społeczno-kulturową instytucją, w której realizują się projekty nie tylko związane z edukacją, ale także z integracją i obywatelstwem społecznym wytyczone przez państwo w ramach polityki integracyjnej i równościowej (Bartz 2007; Bygne 2012; Smith 2013).

Szkoła, jako jeden z fundamentalnych instytucjonalno-społecznych filarów integracji w społeczeństwie przyjmującym, ma sprzyjać zaspokajaniu ważnych potrzeb emocjonalno-społecznych, tworzeniu pozytywnego klimatu w przestrzeni społecznej (European Commission 2009, 2015). Z jednej strony szkoła ma potencjalny wpływ na zmiany, w pewnym zakresie jej program, postawy i zachowania uczniów wpływają na szersze społeczeństwo (tj. integrację społeczną, ekonomiczną i polityczną). Presja migracyjna, widoczność migrantów w społeczeństwie norweskim, dyskurs wokół migrantów i rodzin migracyjnych nie pozostaje bez wpływu na relacje interetniczne. Aktywuje stereotypy oraz dystanse społeczne i emocjonalne (Godzimirski 2018; Slany, Pustułka 2016). Z drugiej strony wiele napięć wokół migrantów przenika z lokalnych społeczności i transmitowane są one na całe społeczeństwo, przyczyniając się do widoczności, niechęci i uprzedzeń wobec migrantów oraz uprzedzeń samych migrantów wobec większości i państwa norweskiego, a także jego instytucji (np. kontrowersje wokół działalności głównej instytucji systemu ochrony praw dziecka w Norwegii: Służby Ochrony Praw Dziecka - nor. Barnevernet ${ }^{5}$ ).

${ }^{4}$ Na przestrzeni ostatniej dekady Rada i Komisja Europejska podjęły liczne inicjatywy w celu wdrażania adekwatnej polityki integracyjnej w zakresie migracji i edukacji (np. Council conclusions on the education of children with a migrant background - 2009/C 301/07; Joint Report of the Council and the Commission on the implementation of the strategic framework for European cooperation in education and training (ET 2020) - New priorities for European cooperation in education and training). W tych dokumentach podkreśla się m.in. rolę edukacji w procesie integracji dzieci migrantów oraz potrzebę zredefiniowania dotychczasowych działań na rzecz promowania równości i spójności społecznej oraz aktywnego obywatelstwa.

${ }^{5}$ Temat ten dyskutuje Jakub Godzimirski wraz z zespołem (2015; zob. też Godzimirski 2018). Szczegółowe omówienie problematyki związanej z Barnevernet w odniesieniu do Polonii norweskiej oraz stosunków bilateralnych Norwegii i Polski zostanie zawarte w dysertacji Strzemeckiej. 
Im więcej napięć, konfliktów, sporów wokół migrantów, tym mniejsze szanse na pełną integrację.

Środowisko szkolne jest przestrzenią, w której uwidacznia się proces interkulturowej, interetnicznej, narodowej konfrontacji uwydatniającej różnice i nierówności (np. ekonomiczne, społeczne, płciowe, religijne czy te związane ze stylem życia). Podkreśla się, że szkoła jest przestrzenią społeczną, interakcyjną, w której krzyżują się doświadczenia różnorodności kulturowej, spotkania wieloetnicznego, różnicy płciowej, klasowej, pochodzenia, przynależności, inności/obcości. W związku z powyższym w perspektywie „diagnostycznej” narzuca się pytanie: czy norweskie środowisko szkolne sprzyja znoszeniu (egalitaryzm) czy utrwalaniu i pogłębianiu (elitaryzm) nierówności społecznych? Etniczne tło szkoły samo w sobie nie jest źródłem podziałów i nierówności, lecz w połączeniu (krzyżowaniu się) z takimi czynnikami jak: płeć, wiek ucznia, status społeczno-ekonomiczny, cechy zewnętrze (wygląd, ubiór, zachowanie), dystynkcje społeczne i ekonomiczne nabierają znaczenia ${ }^{6}$. Odziaływanie wzajemne tych czynników wpływa również na atmosferę w szkole, a ta z kolei oddziałuje na relacje między uczniami.

Przyjmujemy, iż relacje w środowisku rówieśniczym odzwierciedlają się na poziomie indywidualnym oraz w grupie rówieśniczej i wzajemnie na siebie oddziałują (zob. Wykres 1). Na poziomie indywidualnym istotne znaczenie mają cechy osobowościowe i statusowe, które posiadają dzieci i które przynoszą ze sobą do szkoły. Tutaj ważne są cechy zsocjalizowane w rodzinie polskiej i doświadczonej migracyjnie (socjalizacja poprzez migrację i socjalizacja w migracji). Na poziomie indywidulanym istotne jest również, co dzieci robią wzajemnie dla siebie i jak ta aktywność wpływa na relacje koleżeńskie. Grupa wyłania się poprzez afektywne stosunki, zachowania i oddziałuje na swoich członków.

Dobre i trwałe relacje w środowisku szkolnym to jedno z najważniejszych zagadnień dla każdego młodego człowieka, szczególnie na emigracji. Dla dzieci w wieku szkolnym coraz większą wartość ma opinia rówieśników, mniejszą dorosłych (rodziców czy nauczycieli). Niemniej jednak w grupach rówieśniczych nierzadko dochodzi do antagonizmów, które mogą przybierać rozmaite formy zachowań i postaw ignoranckich, aroganckich czy agresywnych. W każdej szkole - niezależnie od kontynentu i kraju - są dzieci odrzucane, nieakceptowane i szykanowane przez rówieśników z rozmaitych powodów (dobre/złe rezultaty w szkole, (nie)markowe ubrania, brak/ przestarzałe gadżety elektroniczne, wysoka/niska pewność siebie, przynależność etniczna etc.). Jednym z przejawów dyskryminacji w szkole jest zjawisko określane „bullyingiem”.

${ }^{6}$ W artykule przyjmujemy definicję nierówności społecznych za Henrykiem Domańskim (2007: 37): „Nierówności są formą zróżnicowania, która występuje w postaci hierarchii pozycji i zasobów, takich jak władza, dochody, prestiż czy dobra kultury".

7 Za główne wskaźniki statusu rodziny można przyjąć: dochód, wykształcenie, zawód, warunki mieszkaniowe, miejsce zamieszkania, status zdrowotny, uczestnictwo w kulturze i aktywnościach dodatkowych. 


\section{SM̂PP}

Wykres 1 .

Czynniki wpływające na relacje w środowisku szkolnym - kompleks krzyżujących się cech

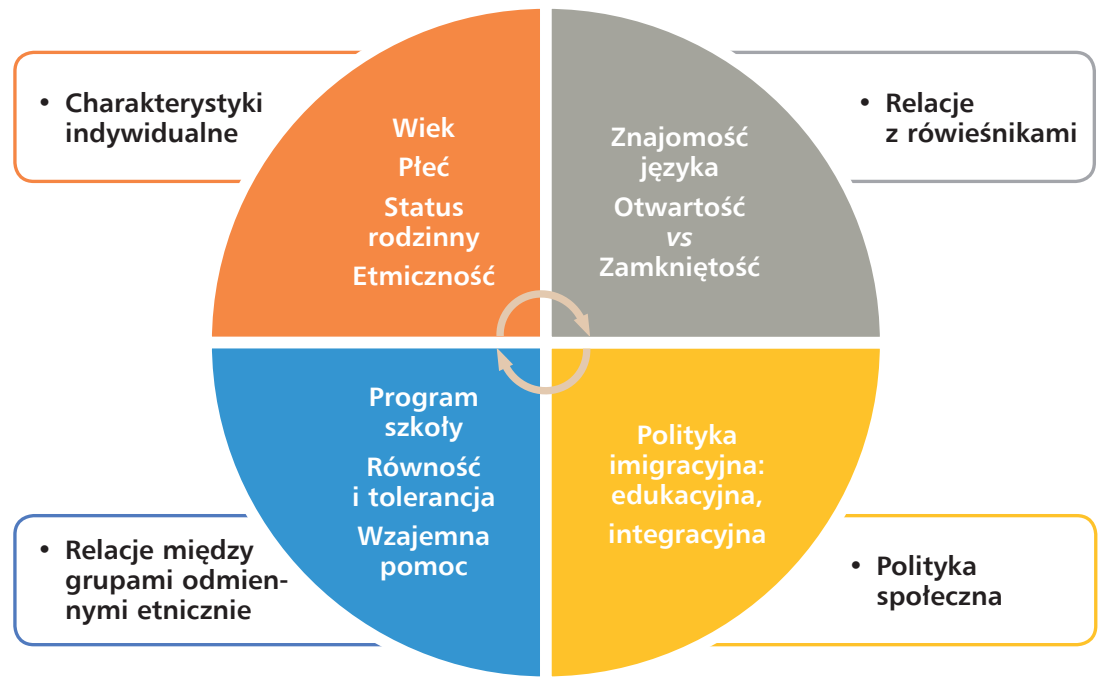

Źródło: Opracowanie własne na podstawie przeprowadzonych badań.

Dan Olweus (2007) twierdzi, że o bullyingu można mówić wówczas, gdy dziecko przez dłuższy czas narażone jest na wielokrotne negatywne działania (przybierające zarówno formy bezpośrednie i pośrednie, werbalne i niewerbalne, mające miejsce w życiu realnym i wirtualnym - tzw. cyberbullying) ze strony jednej osoby lub grupy sprawców. Do typowych działań negatywnych, skierowanych wobec dręczonych dzieci, zalicza się (Ibid.): drwienie, ośmieszanie, poniżanie, przezywanie, szykanowanie, grożenie z użyciem siły, wykluczanie z grupy, ignorowanie potrzeb, bicie, popychanie, szczypanie, obrzucanie przedmiotami, chowanie, zabieranie, uszkadzanie czyjejś własności oraz wszystkie inne zachowania, które zmierzają do skrzywdzenia danej osoby. Z kolei do najbardziej charakterystycznych cech zjawiska bullyingu zalicza się (Szkatuła 2011: 328): (1) długotrwałość (dręczenie trwa minimum kilka miesięcy); (2) powtarzalność (ma charakter ciągły); (3) nierównowagę sił między prześladowcą a ofiarą; (4) negatywne skutki dla ofiary; (5) niejawność (występuje zazwyczaj wtedy, gdy ofiara znajduje się w obecności sprawców); (6) celowość (dokuczanie jest działaniem celowym, choć może być nieuświadamiane) ${ }^{8}$.

Ofiarami bullyingu są najczęściej osoby, które w grupie rówieśniczej zajmują pozycję outsidera. Outsiderami są uczniowie, którzy wyróżniają się na tle społeczności

8 Jeszcze na początku XX w. przemoc rówieśnicza uważana była za „normalne” zjawisko. Kształtowanie porządku i hierarchii opartej na zasadzie „kto silniejszy, ten lepszy” było traktowane jako „naturalne" w dynamice grupowej. Współcześnie, m.in. pod wpływem nowych nurtów pedagogicznych i teorii wychowania (Śliwerski 2007), przemoc w środowisku szkolnym przestała być społecznie akceptowalna. 
klasowej i/lub szkolnej (zob. Olweus 2007). Są to osoby, które - jak wskazuje Joanna Gajda i Seweryn Cichoń (2006) - „(...) pochodzą z innej okolicy, kraju, mówią w niezwykłym dialekcie, ich wygląd fizyczny zwraca uwagę, zachowują się inaczej, reprezentują inne poglądy polityczne lub wyznanie (...)". Naukowcy, zajmujący się konsekwencjami przemocy w środowisku szkolnym, wskazują na różnorodność skutków tego zjawiska dla ofiary. Wyróżnia się trzy grupy skutków (Szkatuła 2011: 335): (1) następstwa psychiczne: depresja, nerwice, natręctwa, zakłócenia koncentracji uwagi, próby samobójcze; (2) następstwa psychosomatyczne: jadłowstręt, schorzenia żołądka i układu pokarmowego, zakłócenia pracy serca, oddechu, zakłócenia snu, nadmierne napięcie mięśni, bóle głowy; oraz (3) zmiany zachowania i unikanie sytuacji wzbudzających lęk, wycofanie się z kontaktów społecznych, wzrost poziomu agresji, hiperaktywność lub apatia, utrata zainteresowania otoczeniem (por. Aarø 2016).

Norwegia jest uważana za kraj pionierski w zakresie badań nad mobbingiem szkolnym i projektowania oraz wdrażania programów antymobbingowych od lat 70. XX w. ${ }^{9}$ Jednak mimo szeroko zakrojonych i systematycznych antydyskryminacyjnych działań z badań wiemy (Fandrem, Strohmeier, Roland 2009; Fandrem, Strohmeier, Jonsdottir 2012; Sjursø, Fandrem, Roland 2015), że bullying występuje i przybiera różne formy. Choć programy przeciwdziałające nękaniu od dziesięcioleci stanowią integralny element norweskiego systemu edukacyjnego i przynoszą wymierne rezultaty, wyniki badań opublikowane przez norweski Urząd ds. Edukacji (nor. Utdanningsdirektoratet) w 2013 r. pokazały, że problem dręczenia w Norwegii wciąż jest znaczący ok. 63000 uczniów jest regularnie zastraszanych 2-3 razy w miesiącu lub dłużej, co stanowi 10\% populacji Norwegii w wieku szkolnym (Aarø 2016). Dlatego też od 2016 r. rząd wdraża najnowszą strategię walki z nękaniem w norweskich szkołach i przedszkolach zwaną Partnership against bullying przewidzianą na lata 2016-2020 (Ministry of Education and Research 2016: 15).

W obliczu zintensyfikowanej mobilności obywateli EU/EOG/EFTA i obywateli pozostałych krajów, norweska szkoła jest w zamyśle narodowym projektem przygotowującym młodych ludzi do życia w wielokulturowym społeczeństwie. Poważnym wyzwaniem jest kwestia przystosowania się do zróżnicowania kulturowego. Choć polityka społeczna państwa norweskiego wobec dzieci w szkole koncentruje się na promowaniu i praktykowaniu równości (Nikielska-Sekuła 2016; Strzemecka 2015; Ślusarczyk, Wærdahl, Strzemecka 2018), etniczność może być w wielu przypadkach stosowana do ranienia danej jednostki. Z przeglądu badań dotyczących bullyingu w norweskim środowisku szkolnym wynika, iż z tym zjawiskiem mamy do czynienia na każdym etapie edukacyjnym (Olweus, Breivik 2017). Co więcej, dotyczy ono zarówno

${ }^{9}$ Norwegia opracowała kilka programów mających na celu ograniczenie problemu znęcania się w szkołach, m.in. Program Olweus (Olweus Bullying Prevention Program, w skrócie OBPP), Program ZERO oraz Program RESPECT. Międzynarodowe badania ewaluacyjne wykazały (Eriksen, Hegna, Bakken, Lyng 2014; Olweus, Limber 2010), iż jednym z najskuteczniejszych programów antymobbingowych u progu XXI w. był Program Olweus. 
dzieci norweskich, jak i pochodzenia imigranckiego, niezależnie od płci i wieku (Fandrem et al. 2009; Fandrem et. al. 2012; Kalkman et al. 2017; Olweus 2007; Sjurs $\varnothing$ et al. 2015). Zatem bullying (traktowany jako przejaw dyskryminacji) jest w norweskim środowisku szkolnym zjawiskiem aktualnym, ale nie nowym.

\section{Materiały i metody}

Artykuł opiera się na badaniach jakościowych prowadzonych w ramach dwóch projektów badawczych realizowanych w latach 2013-2016: „Doświadczenia dzieci dorastających transnarodowo"10 oraz "Proces adaptacji dzieci polskich imigrantów. Badania terenowe w Norwegii"11. Badania z dziećmi imigrantami, dorastającymi w Norwegii, osadziłyśmy we współczesnym paradygmacie metodologicznym społecznych studiów nad dzieckiem i okresem dzieciństwa (Corsaro 2011; James et al. 1998; Smith 2011), czyli orientacji traktującej dzieci jako aktywnych aktorów społecznych oraz stawiającej ich doświadczenie w centrum procesu badawczego. W tym artykule wykorzystujemy dane pochodzące z: (1) wywiadów pół-ustrukturyzowanych z dziećmi w wieku 6-13 lat (30 wywiadów z dziećmi par intraetnicznych urodzonymi w Polsce), (2) pół-ustrukturyzowanego wywiadu grupowego (tzw. fokusa) z dziećmi w wieku 10-15 lat (wywiad z dziećmi par intraetnicznych urodzonymi w Polsce i Norwegii), (3) wywiadu swobodnego z młodym dorosłym (22-letnim synem pary polsko-polskiej) oraz (4) półustrukturyzowanych obserwacji towarzyszących wywiadom. W prowadzonych badaniach nie miałyśmy możliwości utworzenia grup kontrolnych i konfrontowania negatywnych doświadczeń dzieci w środowisku szkolnym. Omawiane w tym artykule zagadnienia wypłynęły w toku szeroko zakrojonych badań. Dzieci, pytane o szkołę i postępy szkolne, same podnosiły temat zróżnicowań i bullyingu, co skłoniło nas do zajęcia się tymi zagadnieniami.

Przeprowadziłyśmy 30 wywiadów z dziećmi będącymi na etapie norweskiej szkoły podstawowej - Barnetrinnet (28 wywiadów indywidualnych i 2 wywiady z parą rodzeństwa, co dało łącznie 32 uczestników: 20 chłopców, 12 dziewcząt, w tym 10 osób w wieku 6-7 lat, 8 osób w wieku 8-9 lat, 14 osób w wieku powyżej 10 lat).12

10 Tytuł oryg.: Children's experience of growing up transnationally. Zadanie nr 5 stanowiło część projektu Transfam. Zespół zadania nr 5: prof. zw. dr hab. Krystyna Slany (liderka zadania), mgr Stella Strzemecka (badaczka główna), Anna Bednarczyk, Inga Hajdarowicz (badaczki asystujące).

${ }^{11}$ Projekt kierowany i realizowany przez mgr Stellę Strzemecką. Projekt otrzymał finansowanie ze środków DSC na zadania służące rozwojowi młodej kadry naukowej oraz uczestników studiów doktoranckich na Wydziale Filozoficznym UJ. Nr grantu: K/DSC/001889 2013/2014.

12 W Norwegii kształcenie jest obowiązkowe dla osób w wieku od 6 do 16 lat (klasy 1-10). Etap ten nosi nazwę Grunnskole (szkoła podstawowa i średnia I stopnia). Grunnskole dzieli się na Barnetrinnet (etap szkoły podstawowej, który jest przeznaczony dla uczniów w wieku 6-12 lat - klasy 1-7) oraz Ungdomstrinnet (etap szkoły średniej I stopnia dla osób w wieku 13-16 lat - klasy 8-10). Zgodnie z Międzynarodową Standardową Klasyfikacją Wykształcenia ISCED, kształcenie obowiązkowe w Norwegii odpowiada oznaczeniu ISCED $1+2$ (Eurydice 2018). 
Posiadałyśmy ogólny plan badania, który zawierał m.in. takie obszary problemowe jak: (1) rodzina i czas wolny (relacje z rodzicami i rodzeństwem, relacje z dalszymi krewnymi w Polsce i Norwegii, rodzaje i częstotliwość kontaktów, wzory spędzania czasu wolnego); (2) szkoła/nauka i przyjaciele/rówieśnicy (relacje z rówieśnikami i ocena grup rówieśniczych, relacje z nauczycielami i ocena otrzymywanego wsparcia ze szkoły, kompetencje i preferencje językowe, sposoby na integrację i stopień integracji w grupach rówieśniczych), podmiotowość/relacje władzy, przywiązanie do miejsca (lub brak przywiązania), strategie negocjowania tożsamości i przywiązania.

Z kolei wywiad fokusowy objął 5 uczestników (2 chłopców w wieku 10 lat oraz 3 dziewczęta - 2 w wieku 10 lat i jedną w wieku 15 lat). Fokus był przeznaczony dla dzieci w wieku 10-13 lat uczęszczających do ostatnich klas Barnetrinnet, ale 15-latka (uczennica Ungdomstrinnet), zgłosiła się z propozycją uczestnictwa w wywiadzie, aby podzielić się swoimi doświadczeniami związanymi z bullyingiem w norweskim środowisku szkolnym ${ }^{13}$. W trakcie badania fokusowego poruszałyśmy takie zagadnienia jak: (1) ocena szkoły norweskiej (jeśli dotyczyło: w porównaniu z polską); (2) ocena rówieśników i sieci rówieśniczych; (3) sposoby i stopień integracji; (4) odczucie zróżnicowania społecznego występujące między uczniami; (5) dręczenie; (6) strategie negocjowania tożsamości i przywiązania; (7) relacje z nauczycielami; (8) ocena wsparcia ze strony szkoły; (9) preferencje i kompetencje językowe; (10) ocena wsparcia otrzymanego od rodziny.

Zarówno w przypadku wywiadów indywidualnych i z parą rodzeństwa, jak i wywiadu fokusowego - choć badanie miało charakter częściowo ustrukturyzowany - założyłyśmy, że ma odznaczać się wysokim stopniem elastyczności (por. Eder, Fingerson 2002; Heary, Hennessy 2006). Wszystko po to, by podążać za wątkami sygnalizowanymi przez dzieci jako istotne. Natomiast w przypadku wywiadu swobodnego z młodym dorosłym akcent rozmowy został przez samego badanego położony na kwestie związane ze środowiskiem szkolnym i rówieśniczym oraz z relacjami rodzinnymi i dylematami tożsamościowymi z perspektywy cyklu życia.

Materiał empiryczny pozyskałyśmy prowadząc badania w dwóch turach: od stycznia do maja 2014 r. oraz od stycznia do kwietnia 2016 r. Badania realizowałyśmy w Norwegii wschodniej (region Østlandet), zarówno w miastach, mniejszych miejscowościach, jak i na wsiach, głównie w okręgu Oslo, Akershus i Buskerud ${ }^{14}$, ale także Østfold, Vestfold, Hedmark, Oppland oraz Telemark. Rekrutowałyśmy rodziców z dziećmi w oparciu o strategię „kuli śnieżnej” z licznymi punktami dotarcia do badanych. W czasie rekrutacji korzystałyśmy m.in. ze wsparcia ekspertów, znajomych migrantów oraz instytucji polskich i polonijnych. Zastosowana strategia rekrutacyjna umożliwiła nam dotarcie do dzieci z rodzin o zróżnicowanym kapitale i statusie społeczno-ekonomicznym (zob. Tabela 1).

${ }^{13}$ Wątek ten znajdzie swoje rozwinięcie w rozdziale metodologicznym rozprawy doktorskiej Strzemeckiej.

14 Największa grupa Polaków mieszkała w badanym okresie na tym obszarze (Iglicka et al. 2018). 
Charakterystyka badanych rodzin polsko-polskich w Norwegii

\begin{tabular}{|l|l|}
\hline \multicolumn{2}{|l|}{ Rodziny polsko-polskie } \\
\hline Typ rodziny & $\begin{array}{l}\text { Formalne małżeństwa (28) } \\
\text { Samodzielni rodzice (3) } \\
\text { Kohabitujący rodzice (1) }\end{array}$ \\
\hline Średnia liczba dzieci w rodzinie & 1,8 \\
\hline Średni wiek rodziców & 36 \\
\hline Poziom wykształcenia rodziców & $\begin{array}{l}\text { Wyższe (28) } \\
\text { Średnie (ogólne i techniczne) (17) } \\
\text { Zawodowe (12) } \\
\text { Brak informacji (4) }\end{array}$ \\
\hline Okres migracji rodziców & $\begin{array}{l}\text { "Poakcesyjna" fala migracji (po akcesji Polski do UE) - 59 } \\
\text { "Przedakcesyjna” fala migracji (1990-2003) - 2 }\end{array}$ \\
\hline Status zatrudnienia rodziców & $\begin{array}{l}\text { Pracujący (praca najemna/samozatrudnienie) - 57 } \\
\text { Bezrobotny (2) } \\
\text { Niepracujący (opieka nad dziećmi/płatny urlop) - } 2\end{array}$ \\
\hline
\end{tabular}

Źródło: Opracowanie własne.

Zgodnie z protokołem badawczym każde spotkanie z dzieckiem rozpoczynałyśmy od uzyskania zgody od rodziców i dziecka. Wywiady indywidualne i z parą rodzeństwa odbywały się w przestrzeni prywatnej (domach lub mieszkaniach rodziców respondentów - głównie w pokojach dzieci), natomiast wywiad fokusowy z dziećmi i wywiad swobodny z młodym dorosłym miał miejsce w przestrzeni publicznej (w pierwszym przypadku w siedzibie szkoły polonijnej, w drugim w kawiarni). Po każdym wywiadzie wypełniałyśmy siatkę analityczną ( $g r i d)$. Analizę zebranego materiału przeprowadziłyśmy w oparciu o gridy i transkrypcje. Imiona osób badanych zostały zmienione. Wszystkie przytaczane w tym artykule fragmenty wypowiedzi zawierają oryginalną pisownię ${ }^{15}$.

\section{Rezultaty i dyskusja wyników badań}

Z badań wynika, że dla dzieci polskich imigrantów relacje z rówieśnikami w norweskim środowisku szkolnym są jednym z najważniejszych punktów odniesienia w doświadczaniu i rozumieniu różnic oraz podziałów społecznych charakteryzujących

15 Więcej na temat wszystkich - zastosowanych w ww. projektach - technik oraz protokołu badawczego, harmonogramu badań i pracy w terenie w artykułach: Slany, Strzemecka 2015, 2016a, 2016b, 2017, 2018; Strzemecka 2015. 
współczesne społeczeństwo norweskie. Badania wskazują, że dzieci dostrzegają nierówności w statusie ekonomicznym pomiędzy swoimi rodzinami i rodzinami norweskich rówieśników oraz doświadczają bullyingu w środowisku szkolnym (17 na 38 uczestników badania dostrzega nierówności, z kolei 8 na 38 uczestników doświadcza/ło bullyingu). Z badań wynika, że norweskie środowisko szkolne jest przestrzenią ambiwalentną. Z jednej strony sprzyja znoszeniu, z drugiej - powstawaniu i zarazem utrwalaniu nierówności w wielokulturowym społeczeństwie norweskim. Zobaczmy zatem, co mówią dzieci polskich imigrantów o społecznych nierównościach charakteryzujących kraj, w którym obecnie dorastają - Norwegię, oraz jak przez pryzmat funkcjonowania w społeczeństwie norweskim widzą kraj, w którym częściowo się socjalizowali i wychowywali - Polskę.

\section{Doświadczanie zróżnicowania w statusie ekonomicznym}

Zmiana otoczenia szkolnego wymaga przepracowania przez dzieci imigrantów wielu dylematów (m.in. kim jestem, jak jest moja przynależność, jak pozycjonuję innych i siebie samego względem innych, czy jestem lubiany/a, czy/jakich mam kolegów/ przyjaciół, jakie mam osiągnięcia szkolne?). Uczniowie imigranci mogą odczuwać i doświadczać w środowisku szkolnym inności/obcości, co obrazuje poniższy rysunek.

Rysunek 1 .

Inność/obcość w percepcji dzieci imigrantów
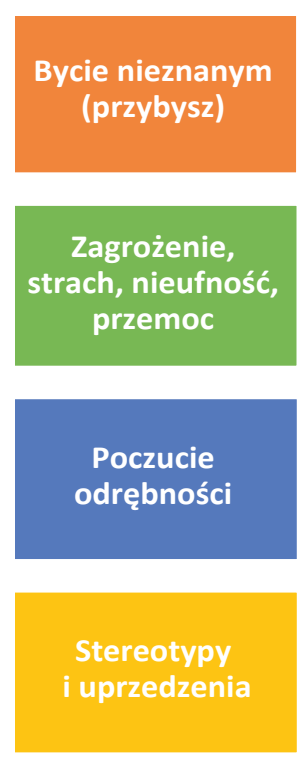
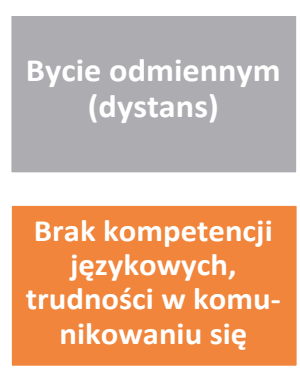

Trudne emocje (złość, smutek, lęk etc.)

\section{Poziom}

zamożności kraju

pochodzenia

i przybycia

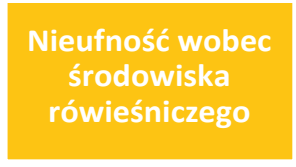

Odmienność

kulturowa

i stylu życia

\section{Poszukiwanie}

wspólnej pła-

szczyzny zainte-

resowań i zabawy

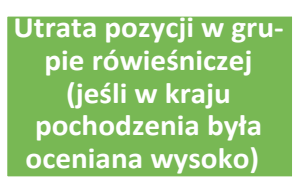

Brak

przewidywalności

Ekskluzja,

wykluczenie

Wieloetniczność

Widoczność

Źródło: Wykorzystanie i dopracowanie w kontekście dzieci polskich imigrantów w Norwegii na podstawie analiz

M. Golki (2010) zawartych w: „Imiona wielokulturowości”, s. 174. 


\section{SM̂PP}

Twierdzi się (np. Wærdahl 2016), że dzieci polskich imigrantów są w norweskim środowisku szkolnym "niewidoczne”, tzn. mają taki sam kolor skóry, na ogół ubierają się i zachowują podobnie jak większość norweskich rówieśników etc. W związku z tym zakłada się, że ich integracja powinna przebiegać szybko (w porównaniu z dziećmi z uboższych - od Polski - krajów i/lub z dziećmi o innym kolorze skóry). Jednakże badania pokazują (Strzemecka 2015), że niewidoczne dzieci istnieją tylko w percepcji dorosłych (tj. pewnych badaczy, rodziców oraz praktyków; nauczycieli, pracowników socjalnych etc., por. Ślusarczyk et al. 2018). Badania z dziećmi wyraźnie wskazują (Strzemecka 2015), że dzieci m.in. ze względu na status migranta (materialny, społeczny, kulturowy) - szczególnie w początkowych fazach post-migracyjnych - są traktowane przez rówieśników jako widoczne, dlatego czują się "tymczasowo widoczne" (Ibid.: 81, 84). Młodzi badani podkreślają przy tym, że nie chcą się wyróżniać, ponieważ widoczność może uruchomić proces segregacji rówieśniczej.

Z analizy wynika, że dzieci polskich imigrantów nie tylko posiadają wiedzę o świecie i ludziach, ale także o różnicach między nimi. Wiedzę tę zapośredniczają głównie ze środowiska szkolnego. Dzieci starają się opisać, wyjaśnić, a w niektórych przypadkach również i ocenić zjawisko nierówności ekonomicznych. Analizy nierówności w norweskim środowisku szkolnym z perspektywy dzieci pokazują, że zarówno te w skali makro-, jak i interpersonalne w skali mikrospołecznej istnieją. Sposób pozycjonowania dzieci (outsider/insider) rozwija się głównie poprzez odkrywanie statusu materialnego, pochodzenia etnicznego oraz kompetencji językowych społeczeństwa przyjmującego.

Kluczem do zrozumienia dynamicznych mechanizmów relacyjnych w obrębie pola szkolnego ${ }^{16}$ okazał się status materialny. Odgrywa on bowiem znaczącą rolę we współczesnym norweskim środowisku szkolnym. W interakcjach szkolnych i relacjach międzygrupowych normy, wartości, wytwory kulturowe (oznaki statusu) są podkreślane w sposób szczególny. Dzieci często wskazywały, że Norwegia to „bogaty kraj" (por. Hakkarainen 2018), oraz że Norwegowie mają "inny sposób rozmawiania”. Z wywiadów z dziećmi dowiadujemy się, że w społeczeństwie norweskim istnieje jawność zarobków oraz obnoszenie się z poziomem zamożności rodziny w szkole, co przez niektóre dzieci polskich imigrantów jest oceniane negatywnie.

(...) oni [Norwegowie - przyp. autorki] mają inny sposób rozmawiania, pytają ile zarabia twój tata, (...) a ile twoja mama zarabia (...). Oni się po prostu bardziej obchodzą [sic!]. Norwegia to jest bardzo bogaty kraj. (...) Ale bez przesady, żeby rozmawiać o pieniądzach w szkole.

Wojciech 12 lat, 7 lat w Norwegii

${ }^{16}$ Pole społeczne może być rozumiane jako sieć lub konfiguracja „obiektywnych relacji między pozycjami" (Bourdieu, Wacquant 1991: 78). 
Manifestowanie oznak posiadanego bogactwa wyznacza pozycje, podnosi prestiż w środowisku szkolnym. Czynnik migracji (przybycie z Polski) aktywizuje wśród dzieci pewne stereotypy. Jako te przybyłe z mniej zamożnego kraju często są poddawane ocenie rówieśników ze względu na status ekonomiczny rodziny, a także ubiór, zachowanie, kompetencje języka norweskiego czy styl życia. W konsekwencji prowadzi to do (re)produkowania hierarchii koleżeńskich.

I zauważalna była presja, że wszyscy byli bardzo tadnie ubrani i markowo (...) nie wszyscy, ale niektórzy po prostu odrzucają tych, co są gorzej ubrani, albo mają inne ubrania, nie mają możliwości, gorszy samochód (...).

Karol 22 lata, 9 lat w Norwegii

Co istotne z perspektywy dalszych badań nad zróżnicowaniami materialnymi w kontekście migracji, wywiady z dziećmi sugerują, iż miejsce, w którym żyją, ma kluczowe znaczenie w procesie budowy, utrzymania i reprezentacji różnic społecznych i ekonomicznych. Z badań jasno wynika, że mimo młodego wieku dzieci potrafią relatywizować pojęcie bogactwa (,tu” - w Norwegii i „tam” - w Polsce). Tym samym odnoszą rozumienie zróżnicowań nie tylko do ogólnego poziomu zamożności czy wykształcenia, ale także do miejsca zamieszkania (zob. Hakkarainen 2018).

A co to znaczy słowo bogata w Polsce a tutaj [w Norwegii]?! Tutaj bogata to jest koleżanka moja a nie ja. W Polsce dla nich ja jestem bogata a nie one. (...) One myślą, że bogata to znaczy mieć swój własny dom, powiedzmy psa, telewizor, dwa Play Station. Coś tam, coś tam. A dla innych [w Norwegii] bogata to znaczy jacuzzi i reszta. (...) więc to jest trochę wkurzające, że ktoś do ciebie podchodzi i mówi: "tat, jeżeli masz iPhona, to jesteś bogata (...).

Katarzyna 13 lat, 3 lata w Norwegii

Po emigracji do Norwegii Katarzyna uzmysłowiła sobie, że bezpowrotnie straciła wypracowywaną przez lata w Polsce pozycję w grupie rówieśniczej (zob. Strzemecka 2015), więc musiała rozpocząć proces budowania relacji od nowa. Choć początki na emigracji były dla Katarzyny trudnym, pełnym wyzwań okresem w życiu (szczególnie kontakty interetniczne powiązane z kodami kulturowymi - m.in. z tzw. Prawem Jante ${ }^{17}$ ), dziewczyna marzy o dużym domu, w którym mogłaby zamieszkać w Norwegii z całą swoją rodziną. By osiągnąć ten cel, Katarzyna konsekwentnie planuje budowanie pozycji w norweskim polu szkolnym. Można wysunąć tezę, iż dzieci liczą na przesuwanie się z biegiem lat na coraz wyższe pozycje w hierarchii rówieśniczej i osiągnięcie wymarzonej wysokiej pozycji społecznej.

17 Prawo Jante (nor. Janteloven) jest stereotypem etnicznym, opisującym zachowania mieszkańców krajów nordyckich. To nieformalne prawo ma swoje korzenie w noweli Aksela Sandemose'a (1933) pt. "Uciekinier w labiryncie” (En flyktning krysser sitt spor). Sandemose ukazał fikcyjne duńskie miasteczko Jante, którego mieszkańców obowiązuje 11 zasad, opierających się m.in. na takich wartościach jak: skromność, przeciętność, nie wywyższanie się. 


\section{SM̂PP}

(...) to, co tam [w Polsce] zdobyłam, tak jakby tu [w Norwegii] straciłam. Musiałam tutaj zacząć od początku, ale potem się przyzwyczaiłam i powiedziałam, że jeżeli się znowu przeprowadzimy do Polski, to że wszystkich ukatrupię. Od tamtej pory jest zupełnie inaczej niż było $w$ Polsce. (...)

Katarzyna 13 lat, 3 lata w Norwegii

\section{Bullying i „praca rówieśnicza”}

W norweskiej szkole realizowane są liczne edukacyjne działania antybullyingowe. Na przykład na zasadę mówienia i pokazywania „stop” wskazuje Honorata:

(...) jest u nas w szkole zasada (...), że jeżeli ktoś ci dokucza albo coś ci robi, to mówisz „stop". (...) i wtedy nie robi ci tak.

Honorata 10 lat, 9 miesięcy w Norwegii

Jednakże w praktyce, ze spotkania wieloetnicznego, ścierania się różnorodności i odczuwania inności/obcości, może wypływać wiele zróżnicowań i nierówności, w tym przejawów nierównego traktowania w formie bullyingu, związanego z nierównowagą sił. Z przeprowadzonych badań wynika, że doświadczenia dzieci polskich imigrantów związane z dręczeniem mają na ogół swoje korzenie w pochodzeniu (Polska mniej zamożny kraj), zamożności (niższy status ekonomiczny rodziny) i kompetencjach językowych (niższe kompetencje). Dręczenia ze strony rówieśników (m.in. wykluczania z grupy, drwienia, przezywania, ośmieszania i/lub poniżania) doświadczały dzieci polskich imigrantów, które wyemigrowały do Norwegii w wieku 4 lat i więcej.

(...) od pierwszej klasy, jak chodziłem do szkoły (...) To nie miałem dużo kolegów. Potem w drugiej klasie... (...) Znałem [norweski], ale tak trochę jeszcze było słychać, że ja jeszcze nie jestem z Norwegii. Potem w drugiej klasie było słychać, że jestem z Norwegii, że wszystko dobrze ten... Też w sumie nie miałem kolegów i się kłóciłem często. Znaczy oni się kłócili ze mną, ze mnie się nabijali, tak było do piątej klasy może. W sumie to były dla mnie trochę ciężkie chwile, bo oni mnie jakby odrzucali ze swojego grona, byłem sam.

Wojciech 12 lat, 7 lat w Norwegii

W poprzedniej szkole byłam lubiana i bardzo znana. Byli w niej i Norwegowie i osoby na przykład z Pakistanu. Ale w nowej szkole jest problem taki, że NIKT w klasie nie chce się ze mną zaprzyjaźnić. Ja próbowałam wielokrotnie zaprzyjaźnić z nimi. Jaki temat, żeby rozmawiać o czymś, ale nie pokazują żadnej zachęty ani nic. Po prostu olewają mnie, jakby mnie tam nie było. W klasie wszyscy są Norwegami. Ja z moją koleżanką jesteśmy Polki, więc my się razem trzymamy, bo jak oni nie chcą się z nami przyjaźnić. 
Bullying może być zakorzeniony w codziennych działaniach realizowanych W "strefach wolnych od dorosłych" (ang. adult-free zones) takich jak szatnie, toalety, place zabaw czy Internet (cyberbullying) (Kalkman et al. 2017: 23-24, 34). W przypadku naszych badań były to klasy, korytarze, place zabaw oraz Internet.

(...) jak bym teraz przyszedł do szkoły, to nikt by nie wiedziat, że jestem z Polski. Wzięliby mnie za Norwega (...), ale czasami moja koleżanka tak do mnie mówi jak sobie czasami gramy w gry na komputerze: "okej, gdzie jesteś Polaku?" Tak na żarty ona to robi, tak na serio to nie, na żarty, gdy mnie szuka.

Oliwer 11 lat, 3 lata w Norwegii

Młody dorosły również wspominał, że był dyskryminowany przez niektórych - jak określa ich nasz rozmówca - „pogrupowanych”. ${ }^{18}$ Do aktów bullyingu (wykluczania, drwienia, ośmieszania) dochodziło zazwyczaj w czasie przerw. Przypadek Karola pokazuje jak nierówności i bullying trwają w norweskiej szkole.

(...) Oni już byli pogrupowani, trzymali się w grupach (...). W ogóle nie rozumiałem, o co w tym chodzi. Wydawało mi się na początku, że są otwarci, ale ja nigdy nie byłem przyzwyczajony, że by jakieś ugrupowania. (...) bardzo lubili mi dokuczać, więc pamiętam, że często jak koło nich przechodzitem to (...) starałem się zawsze być mitym dla wszystkich, więc jak ktoś mnie zaczepit (...), to próbowałem porozmawiać, co tam mogłem, ale pamiętam kilka razy byłem zaczepiony i chcieli żebym coś powiedziat, jakieś zdanie. Jak to powiedziałem, to oczywiście słyszeli, że było dziwnie i się śmieli oczywiście i ja wtedy też udawatem, że to jest śmieszne, ale robienie z siebie klauna nie jest wcale takie fajne. (...) To było nieprzyjemne, więc być może te grupy czy osoby, które to [niskich kompetencji z norweskiego] używały przeciwko mnie, jeżeli one by tego nie robity, to [doświadczenie szkolne] byłoby to pozytywne. Ale akurat w moim przypadku nie miałem fuksa.

Karol 22 lata, 9 lat w Norwegii

Dzieci polskich imigrantów deklarowały również, iż doświadczały takich agresywnych działań ze strony rówieśników jak grożenie użyciem siły, popychanie czy bicie. Wśród naszych badanych para rodzeństwa - 8-letni Sylwester i 9-letni Jacek - była bita przez blisko pół roku. Z relacji chłopców i ich matki wynika, że doświadczali oni przemocy fizycznej ze strony dzieci afrykańskich imigrantów. Po interwencjach matki sytuacja uległa poprawie - na każdej przerwie chłopcom towarzyszy asystent.

(...) lepsza polska szkoła niż norweska, bo ciągle tam się biją [na przerwach] (...), bo w Polsce to nikt jeszcze nie wymyślit, żeby się bić w szkole.

Jacek 9 lat, od roku w Norwegii

${ }^{18}$ W celu poszerzenia zgromadzonego materiału badawczego w ramach projektu Transfam, przeprowadziłyśmy wywiad swobodny z młodym dorosłym (zob. Slany, Strzemecka 2016a). 


\section{SM̂PP}

Bycie imigrantem może generować wiele trudnych - w niektórych przypadkach traumatycznych - doświadczeń, które oddziaływają na całe przyszłe życie społeczne dziecka. Długotrwałe bycie odrzuconym przez grupę rówieśniczą rodzi zmiany w psychice dziecka i może prowadzić np. do depresji, jak w przypadku Karola (por. Aarø 2016). Niemniej jednak, badania odsłaniają również podmiotowość i sprawczość dzieci. Młodzi aktorzy migracji aktywnie działają na rzecz własnej integracji w społeczeństwie przyjmującym. Podejmują liczne działania samopomocowe w celu zmiany swojego nastroju (poprawy samopoczucia i samooceny) oraz pozycji w polu szkolnym.

(...) I w pewnym momencie to spowodowało, że ja się zamknąłem w sobie. Chodziłem do szkoły i w ogóle z nikim nie rozmawiałem. Szedłem do szkoły i dosłownie nie otwieratem buzi, jeśli nie musiałem w ciągu całego dnia. Ja miatem wtedy okres depresji jak teraz na to patrzę to wiem, że to była depresja. W ogóle nie chciało mi się wstawać do szkoły. (...) biegłem na autobus i tylko czekałem aż się skończy szkoła, żeby iść do domu, żeby robić cokolwiek innego. I wtedy albo iść pobiegać, trenować, albo żeby tylko zapetnić czymś czas, aby nie myśleć o tym szkole i tym, co jest dookoła. (...) To jest tak, że jak jesteś przyzwyczajony do tego, że starasz się być w porządku i byłeś lubiany [w Polsce] to tutaj jest ciężko, jak dokuczają. Dużo zależy od człowieka, od jego charakteru. Każdy musi dawać sobie radę z niektórymi rzeczami sam. (...) Z perspektywy czasu przyznaję, że to doświadczenie było dobre. Dzięki temu stałem się bardziej otwarty.

Karol 22 lata, 9 lat w Norwegii

W kontekście odmienności etnicznej, kulturowej, ekonomicznej, odmiennego kapitału dzieci, na potrzeby określenia, rozumienia oraz identyfikowania zróżnicowań wprowadzamy pojęcie "pracy rówieśniczej” (ang. peer work) - pracy w obliczu walki o uznanie przyjaźni, powodzenia w szkole, negocjowania tożsamości i przynależności, nauki jak być silnym i wzmocnić własne "ja”. Pracę rówieśniczą na rzecz niwelowania nierówności i doświadczanego bullyingu w środowisku szkolnym winniśmy traktować jako przejaw podmiotowości i sprawczości dziecka imigranta, chęć wzmocnienia jego/jej ważności oraz pragnienie budowania dialogu międzykulturowego z innymi rówieśnikami' ${ }^{19}$.

\section{Wnioski}

Dla dzieci polskich imigrantów, dorastających w Norwegii, środowisko szkolne kraju napływu stanowi bardzo ważne pole z punktu widzenia przebiegu integracji, kształtowania się samooceny, oceny statusu społeczno-ekonomicznego swojej rodziny oraz oceny poziomu zamożności kraju pochodzenia i przybycia. Z badań wynika, że dzie-

19 Proces pracy rówieśniczej wymaga pogłębionej eksploracji w ramach przyszłych projektów badawczych. 
ci wnikliwie analizują pewne różnice w położeniu społeczno-ekonomicznym, a także akty nierównego traktowania w formie bullyingu. Badane dzieci nie tylko ujawniają istniejące podziały, ale i nierzadko bardzo mocno je przeżywają, odsłaniając ukryte wymiary życia szkolnego w takiej sytuacji badania, która sprzyja odtajnianiu zjawiska dręczenia w szkole.

W norweskim środowisku szkolnym, w kontaktach z rówieśnikami na ogół realizowane jest podejście równościowe. Jednak ze spotkania wieloetnicznego, ścierania się różnorodności i odczuwania inności/obcości wypływa wiele zróżnicowań i nierówności, w tym przejawów nierównego traktowania w formie dręczenia. Badane dzieci często doświadczały negatywnych działań ze strony rówieśników (zarówno w formach werbalnych, jak i niewerbalnych, w życiu realnym i wirtualnym), takich jak: wykluczanie z grupy, drwienie, przezywanie, ośmieszanie oraz poniżanie. Pomimo całego układu zdarzeń niekorzystnych, polscy młodzi imigranci sprawczo działają na rzecz własnej integracji wykonując - jak proponujemy ten proces nazwać - „pracę rówieśniczą". Jest to wysiłek w obliczu walki o uznanie przyjaźni, powodzenia w szkole, negocjowania pozycji w grupach oraz tożsamości i przynależności. Perspektywa biegu życia (przypadek młodego dorosłego) pokazuje długotrwałe emocjonalne przepracowywanie traumatycznych doświadczeń wyniesionych ze środowiska szkolnego. Badania sugerują, że doświadczenie migracyjne może się sprzęgać z przemocą i wzmacniać poczucie dyskryminowania dzieci poddanych bullyingowi, aczkolwiek przypuszczenie to wymaga dalszych systematycznych badań.

Rezultaty naszych analiz wnoszą pewien wkład w rozpoznanie sytuacji dzieci polskich imigrantów w zakresie odczuwania zróżnicowań w statusie ekonomicznym, a także odsłonienia dręczenia w kraju napływu z perspektywy samych dzieci. Rola doświadczeń dzieci imigrantów w tym zakresie może być przydatna w procesie formułowania polityki edukacyjnej i integracyjnej (w tym strategii antybullyingowych) oraz wzmocnienia dyskusji na temat roli etniczności/obcości i „niewidzialności” w środowiskach szkolnych. W ramach aktualnie realizowanych i przyszłych norweskich programów rządowych, mających na celu zapobieganie i ograniczanie tyranizowania oraz zapewnianie przyjaźniejszego środowiska społecznego na etapie edukacji nieobowiązkowej (przedszkolnej) i obowiązkowej (Ministry of Education and Research 2016: 15), sugerujemy rozważenie wdrożenia głównych zaleceń, które wyłoniły się z naszych badań. Obejmują one rekomendacje na czterech poziomach: ministerstwa, szkoły, klasy oraz indywidualnym. Na poziomie ministerstwa proponujemy, by polityka integracyjna i antydyskryminacyjna Norwegii prowadzona w szkołach została wzbogacona o działania osłabiające rolę wysokiego statusu ekonomicznego w środowisku szkolnym w celu niwelowania subiektywnego doświadczania nierówności społeczno-ekonomicznych wśród dzieci z różnych środowisk etnicznych. Na poziomie szkoły sugerujemy organizowanie regularnych spotkań z rodzicami, obejmujących zarówno pogadanki, jak i dystrybucję materiałów informacyjnych (np. przewodnika dla rodziców Utdanningsdirektoratet 2017) oraz wnikliwsze monitorowanie przez 


\section{SM̂PP}

nauczycieli zachowań uczniów. Na poziomie klasy zalecamy kontynuację prezentowania przez nauczycieli jasnych zasad przeciwko nękaniu oraz regularnych spotkań klasowych z uczniami, obejmujących tematykę nierówności społecznych i dręczenia ze szczególnym uwzględnieniem sytuacji dzieci imigranckich zarówno w roli ofiar, jak i sprawców. Natomiast na poziomie indywidualnym, ze strony nauczycieli, rekomendujemy systematyczne przekazywanie jasnych wytycznych do dyskusji z ofiarami i sprawcami przemocy oraz z rodzicami zaangażowanymi w spory uczniów w oparciu o najnowsze ustalenia badawcze.

Podsumowując, waga badań naukowych w obszarze nierówności i dyskryminacji wiąże się nie tylko z opisywaniem negatywnych doświadczeń dzieci imigranckich, ale i ich rozumieniem oraz efektywnym rozwiązaniem na różnych poziomach struktury społecznego świata.

\section{Bibliografia}

Aarø L.E. (2016), Facts about bullying among children and adolescents in Norway, Norwegian Institute of Public Health, https://www.fhi.no/en/mp/children-and-adolescents/childhoodfamily-and-well-being/facts-about-bullying-among-children/ [dostęp: 23.08.2016].

Bartz T. (2007), Sex education in multicultural Norway, "Sex Education" 7(1), 17-33.

Bourdieu P., Wacquant L.J.D. (1991), An Invitation to Reflexive Sociology, Chicago: University of Chicago Press.

Bygnes S (2012), Gender-equality as boundary: 'Gender-nation frames' in Norwegian EU campaign organizations, "European Journal of Women's Studies" 19, 7-22.

Callender M. (2012), The lives of young Polish migrants residing in Northamptonshire. Doctoral thesis. The University of Northampton.

Castels S., Miller M.J (2011), Migracje we wspótczesnym świecie, Warszawa: PWN.

Corsaro W.A. (2011), The Sociology of Childhood (Sociology for a New Century Series). London: Pine Forge Press, SAGE Publication Inc.

Darvin R., Norton B. (2014), Social Class, Identity, and Migrant Students, "Journal of Language, Identity \& Education", 13(2), 111-117.

Domański H. (2007), Struktura społeczna, Warszawa: Scholar.

Eder D., Fingerson L. (2002), Interviewing children and adolescents, w: J. Gubrium, J. Holstein (red.), Handbook of Interview Research, London: Sage, 181-202.

Eurydice (2018), Diagramy europejskich systemów edukacji 2017/18, Wydawnictwo FRSE, http:// czytelnia.frse.org.pl/media/DIAGRAMY-sk\%C5\%82ad-calosc.pdf [dostęp: 6.02.2019].

European Commission (2009), Council conclusions of 26 November 2009 on the education of children with a migrant background (2009/C 301/07), "Official Journal of the European Union", https://eur-lex.europa.eu/legal-content/EN/TXT/PDF/?uri=CELEX:52009XG1211(01) \&from =EN [dostęp: 29.07.2017].

European Commission (2015), Joint Report of the Council and the Commission on the implementation of the strategic framework for European cooperation in education and training (ET 2020) - New priorities for European cooperation in education and training (2015/C 417/04), "Official Journal of the European Union", https://eur-lex.europa.eu/legal-content/EN/TXT/PDF /?uri=CELEX:52015XG1215(02)\&from=EN [dostęp: 29.07.2017]. 
Eriksen, I.M., Hegna, K., Bakken, A., Lyng, S.T. (2014), Felles fokus. En studie av skolemiljøprogrammer i norsk skole, NOVA Rapport 15/14, Oslo: Velferdsforskningsinstituttet NOVA.

Faist T. (2016), Cross-Border Migration and Social Inequalities, "Annual Review of Sociology" 42, 323-346.

Fandrem H. Strohmeier D., Roland, E. (2009), Bullying and Victimization among Native and Immigrant Adolescents in Norway: The Role of Proactive and Reactive Aggressiveness, "Journal of Early Adolescents" 29(6), 898-923.

Fandrem H., Strohmeier S. Jonsdottir K.A. (2012), Victimization and peer groups among native and immigrant adolescents in Norway, "Emotional and Behavioural Difficulties" 17, 3-4.

Friberg, J.H., Arnholtz J., Eldring L., Hansen N.W., Thorarins F. (2014), Nordic Labour Market Institutions and New Migrant Workers: Polish Migrants in Oslo, Copenhagen and Reykjavik, "European Journal of Industrial Relations" 20(1), 37-53.

Gajda J., Cichoń S. (2006), Przyczyny i przejawy mobbingu, „Gazeta Szkolna. Aktualności” nr 19$-20,30$.

Godzimirski J., Stormowska S., Dudzińska K. (2015), New European Diasporas and Migration Governance: Poles in Norway, https://www.pism.pl/files/?id_plik=20570 [dostęp: 26.06.2016].

Godzimirski J.(2018), Changing representations of Poles in Norway: what can this mean for the future of Polish diaspora?, w: K. Slany, M. Ślusarczyk, P. Pustułka, E. Guribye (red.), Transnational Polish Families in Norway: Social Capital, Integration, Institutions and Care, Frankfurt am Main: Peter Lang, 95-120.

Golka M. (2010), Imiona wielokulturowości, Warszawa: MUZA.

GUS (2015), Informacja o rozmiarach i kierunkach czasowej emigracji z Polski w latach 2004-2014, http://stat.gov.pl/obszary-tematyczne/ludnosc/migracje-ludnosci/informacja-orozmiarach-ikierunkach-czasowej-emigracji-z-polski-w-latach-2004-2014,11,1.html [dostęp: 5.10.2015]. Hakkarainen M. (2018), Experiencing Inequality: Children Shaping Their Economic Worlds in a Translocal Context, w: L. Assmuth, M. Hakkarainen, A. Lulle, P.M. Siim (red.), Translocal Childhoods and Family Mobility in East and North Europe, Palgrave Macmillan: 139-161.

Heary C, Hennessy E. (2006), Focus groups versus individual interviews with children: A comparison of data, "The Irish Journal of Psychology", 27(1-2).

Huang L., Kochowicz M., Krzaklewska E., Pustułka P. (2015), Transfam Web-survey on Polish families living in Polish-Norwegian transnationality: Documentation of design, variables and measurements, http://www.transfam.socjologia.uj.edu.pl/documents/32445283/2f8f4dbce854-4c25-ba1f-a8262fb70f89 [dostęp: 27.01.2016].

Iglicka K., Gmaj K., Wierzejski A. (2018), Contextualizing Polish Migration to Norway in the light of theory, statistical data and research findings, w: K. Slany, M. Ślusarczyk, P. Pustułka, E. Guribye (red.), Transnational Polish Families in Norway: Social Capital, Integration, Institutions and Care, Frankfurt am Main: Peter Lang, 43-70.

James A., Jenks C., Prout A. (1998), Theorizing Childhood, Cambridge: Polity Press.

Kalkman K., Hopperstad M.H., Valenta M. (2017), 'Do you want this?' Exploring newcomer migrant girls' peer reception in Norwegian day care: Experiences with social exclusion through the exchange of self-made artefacts, "Contemporary Issues in Early Childhood" 18(1), 23-38.

Kempny M. (2011), Interpretative Repertoire of Victimhood: Narrating Experiences of Discrimination and Ethnic Hatred among Polish Migrants in Belfast, "Anthropological Journal of European Cultures", 20(1), 132-151. 


\section{SM̂PP}

Lafleur, J-M, Stanek S. (2016), (red), South-North Migration of EU Citizens in Times of Crisis, Dordrecht: Springer.

Ministry of Education and Research (2016), Ninth Consultation on the Implementation of the Convention and Recommendation against Discrimination in Education (1960), National report Norway, Oslo, July 2016 http://www.unesco.org/education/edurights/media/resources/file/Final_version_9th_report_on_Convention_against_Discrimination_in_Education_-.pdf [dostęp: 29.05.2017].

Navas M. S., Rojas A. J., García M. C., Pumares P. (2007), Acculturation strategies and attitudes according to the relative acculturation extended model (RAEM): The perspectives of natives versus immigrants, "International Journal of Intercultural Relations", 31, 67-86.

Nikielska-Sekuła K. (2016), Selected Aspects of Norwegian Immigration Policy Towards Children, "Central and East European Migration Review" 5(1), 129-144.

Oberg K. (1960), Culture Shock: Adjustment to New Cultural Environments, "Practical Anthropology" 7, 177-182.

Olweus D. (2007), Mobbing - fala przemocy w szkole. Jak ją powstrzymać?, Warszawa: Santorski $\& C O$.

Olweus D., Limber S.P. (2010), The Olweus Bullying Prevention Program: Implementation and evaluation over two decades, w: S.R. Jimerson, S.M. Swearer, D.L. Espelage (red.), The handbook of school bullying: An international perspective, New York: Routledge, 377-402.

Olweus D., Breivik K. (2017), Mobbing i skolen - grunnleggende fakta og tiltak med Olweusprogrammet, w: I K.-I. Klepp, L.E. Aarø (red.), Ungdom, livsstil og helsefremmende arbeid, Oslo: Gyldendal Akademisk, 372-398.

Pasamonik B. (2013), Rola płci w integracji europejskich muzułmanów, Kraków: Nomos.

Pustułka P., Ślusarczyk M., Strzemecka S. (2016), Polish Children in Norway: Between National Discourses of Belonging and Everyday Experiences of Life Abroad, w: Z. Millei, R. Imre (red.), Childhood and Nation. Interdisciplinary Engagements, New York: Palgrave MacMillan, 207-227.

Sam D.L., Berry J.W. (2006) (red.), The Cambridge handbook of acculturation psychology, Cambridge: Cambridge University Press.

Sandemose A. (1933), En flyktning krysser sitt spor: fortelling om en morders barndom, Oslo: Tiden Norsk Forlag.

Sauer B., Ajanović E. (2012), Schools as "Protected space"? Good practices but lack of resources: the case of Austria, w: Z. Medarić, M. Sedmak (red.), Children's voices: Interethnic Violence in the School Environment, Koper, Annales University Press, 85-120.

Seeberg M.L. (2011), A Norwegian elephant in the room: ethnic discrimination of children and young people. Migration: Economic Change, Social Challenge. NORFACE Research Programme on Migration/Centre for Research, 1-12.

Sime D. et al. (2017), Eastern European Young People in Brexit Britain: Racism, anxiety and a precarious future Research and Policy, Briefing No.1 http://www.migrantyouth.org/files/2016/08/ Eastern-European-Young-People-in-Brexit-Britain.pdf [dostęp: 27.12.2017].

Sjursø I.R., Fandrem H., Roland E. (2015), Emotional problems in Traditional and Cyberbullying, "Journal of School Violence" Published online January 15. 2015.

Slany K., Strzemecka S. (2015), Gender Roles and Practices in Polish Migration Families in Norway Through the Eyes of Children, "Studia Migracyjne - Przegląd Polonijny" 3(157), 157-181.

Slany K., Strzemecka S. (2016a), Who Are We? Cultural Valence and Children's Narratives of National Identifications, "Central and East European Migration Review" 5(1), 13-34. 
Slany K., Strzemecka S. (2016b), Kapitał rodziny i rodzinności w przestrzeni transnarodowej. Na przykładzie badań polskich rodzin w Norwegii, "Studia Migracyjne - Przegląd Polonijny" 3(161), 255-282.

Slany K., Strzemecka S. (2017), Growing up Multicultural: The Experiences of Children Raised by Polish-Norwegian Mixed Couples in Norway, "Studia Migracyjne - Przegląd Polonijny" 4(166), 87-111.

Slany K., Strzemecka S. (2018), Children as Kin-keepers of a Transnational Family. Inclusive Understanding of a Family in the Eyes of Children, w: K. Slany, M. Ślusarczyk, P. Pustułka, E. Guribye (red.), Transnational Polish Families in Norway: Social Capital, Integration, Institutions and Care, Frankfurt am Main: Peter Lang, 273-296.

Slany K., Pustułka P. (2016), Children, parents and institutions in the mobility maze, "Central and East European Migration Review" 5(1), 5-12.

Smith A.B. (2011), Respecting children's rights and agency, w: Harcourt D., Perry B., Waller T. (red.), Researching Young Children's Perspectives. Debating the ethics and dilemmas of educational research with children, London: Routledge, 11-25.

Smith P.K. (2013), School bulling, "Sociologia, Problemas e Praticas" 71, 81-98.

Sokolowska B. (2016), 'Sharks and Sprats': Polish Immigrant Teenage Children in Ireland, Newcastle upon Tyne, UK: Cambridge Scholars Publishing.

SSB (2018), Immigrants and Norwegian-born to immigrant parents, http://www.ssb.no/en/innvbef/ [dostęp: 27.04.2018].

Strzemecka S. (2015), School Integration in the Eyes of Migrant Children: Based on the Context of Polish Migration to Norway, "Przegląd Socjologiczny" 64(1), 81-110.

Szkatuła J. (2011), Zjawisko mobbingu wśród gimnazjalistów, "Studia Gdańskie. Wizje i rzeczywistość" 8, 326-340.

Śliwerski B. (2007), Pedagogika Dziecka. Studium Pajdocentryzmu, Gdańsk: GWP.

Ślusarczyk M., Wærdahl R., Strzemecka S. (2018). Polish children and their parents adapting to a new school reality in Norway, w: K. Slany, M. Ślusarczyk, P. Pustułka, E. Guribye (red.), Transnational Polish Families in Norway: Social Capital, Integration, Institutions and Care, Frankfurt am Main: Peter Lang, 251-271.

Utdanningsdirektoratet (2017), Guide for parents: if your child does not thrive at school, https:// www.udir.no/laring-og-trivsel/mobbing/guide-til-skoleforeldre-med-barn-som-ikke-har-detbra-pa-skolen/guide-for-parents-if-your-child-does-not-thrive-at-school/ [dostęp: 12.01.2018].

Vertovec S. (2007), Super-diversity and its implications, "Ethnic and Racial Studies" 29(6), 10241054

Wærdahl R. (2016), The invisible immigrant child in the Norwegian classroom: Losing sight of Polish children's immigrant status through unarticulated differences and behind good intentions, "Central and East European Migration Review" 5(1), 93-108.

Zagefka H., Tip L., González R., Brown R., Cinnirella M. (2012), Predictors of majority members' acculturation preferences: Experimental evidence, "Journal of Experimental Social Psychology", 48, 654-659.

Žakelj T., Kralj A. (2012), "It Doesn't Happen in Our School": Ethnicity as a Structural Factor of Peer Violence in Slovenian Schools, w: Z. Medarić, M. Sedmak (red.), Children's voices: Interethnic Violence in the School Environment, Koper, Annales University Press, 21-85. 